\title{
Peranan Polisi Sektor Kajuara dalam Menanggulangi Kenakalan Remaja
}

\author{
Sri Wahyuni Kadir \\ Nursalam \\ Universitas Muhammadiyah Makassar \\ nursalam@unismuh.ac.id \\ Muhammad Akhir \\ Universitas Muhammadiyah Makassar \\ muhammadakhir@unismuh.ac.id
}

\begin{abstract}
ABSTRAK
Masalah utama dalam penelitian ini adalah faktor-faktor yang menyebabkan terjadinya kenakalan remaja di Kecamatan Kajuara Kabupaten Bone dan bagaimana upaya Polsek Kecamatan Kajuara dalam menanggulangi kenakalan remaja.nPenelitian ini adalah jenis penelitian yang menggunakan metode penelitian kualitatif yang bersifat deskriptif dalam bentuk analisis yuridis sosiologis. Metode penelitian kualitatif sebagai prosedur penelitian yang menghasilkan data deskriptif berupa kata-kata tertulis atau lisan dari orang-orang dan perilaku yang dapat diamati. kualitatif deskriftif, meliputi rangkaian kegiatan yang sistematik untuk mendapatkan jawaban atas permasalahan yang diajukan. Hasil penelitian menunjukkan bahwa: (1) faktor yang menyebabkan terjadinya kenakalan remaja di Kecamatan Kajuara Kabupaten Bone yaitu faktor Biologis, Psikogenis, Sosiogenis, dan Subkultural (2) Peranan Polisi Sektor Kajuara dalam menanggulangi kenakalan remaja yaitu dengan pendekatan-pendekatan kepada tokoh-tokoh agama dan masyarakat agar dapat membimbing dan menasehati para remaja agar menghindari perbuatan yang melawan hukum; Melakukan patroli rutin untuk meminimalisir terbukanya kesempatan remaja berperilaku menyimpang, selain itu juga melakukan rasia minuman beralkohol, obat-obat terlarang, senjata tajam, dan barang-barang lainnya yang berpotensi menimbulkan gangguan keamanan dan ketertiban di tempat-tempat tertentu; Melakukan penegakkan hukum dengan melaksanakan proses hukum pada remaja-remaja yang melakukan kejahatan sesuai peraturan perundang-undangan yang berlaku.
\end{abstract}

Kata kunci : Peranan, Penanggulangan, Kenakalan Remaja.

\section{PENDAHULUAN}

Usia remaja merupakan fase peralihan dari masa anak-anak menuju dewasa, dimana pada fase ini remaja mengalami banyak perubahan yang cukup signifikan baik pada jasmani, akhlak, sosial, tingkat emosi termasuk juga cara bertindak dan berpikir. Perubahan yang cepat tersebut membuat remaja terkadang tidak siap secara mental dalam menjalani hidup dan kehidupannya, benang merahnya bahwa remaja diperhadapkan antara harapan dan kenyataan dimana fase ditinggalkannya usia anak-anak yang penuh dengan kelemahan dan ketergantungan tanpa memikul sesuatu tanggungjawab menuju 
kepada usia dewasa yang diperhadapkan pada tanggungjawab penuh dalam menjalani hidup dan kehidupannya. Remaja melekat dengan jiwa-jiwa yang labil yang selalu dipenuhi dengan kegoncangan emosi, sibuk mencari pegangan hidup, dan sibuk juga menuntut ilmu untuk bekal dalam usia dewasanya kelak. Kondisi seperti ini remaja pada hakekatnya sementara berjuang untuk menemukan jati dirinya sendiri. Apabila kondisi tersebut tidak didukung oleh lingkungan yang serasi dan aman, maka dengan mudahnya mereka akan diperhadapkan pada ketidak pastian atau kebimbangan, kecamasan, dan kesengsaraan pada akhirnya remaja akan mengalami kelainan tingkah laku yang akan membahayakan dirinya sendiri dan pada akhirnya memunculkan kenakalan remaja. Kenakalan remaja merupakan fenomena sosial yang marak terjadi dan berimplikasi melanggar hukum serta memberi dampak negatif secara horizontal pada masyarakat sekitarnya dan secara vertikal pada pemerintah dan aparat penegak hukum.Kenakalan remaja sudah menjadi masalah nasional saat ini, dimana pemerintah dan aparat penegak hukum mengagendakan penanggulangan kenakalan remaja sebagai prioritas utama. Kenakalan remaja berupa mengganggu ketertiban umum, meresahkan masyarakat seperti adanya geng motor bahkan begal di jalan raya, melakukan keributan-keributan, perkelahian baik kelompok maupun massal, bahkan pembunuhan, sudah bukan merupakan berita langka baik di media cetak maupun elektronik, tetapi sudah menjadi tranding topic dimana-mana.

Fenomena sosial ini tentu memerlukan kepedulian dan kepekaan semua pihak untuk mengambil langkah kongkret dan tepat dalam penanggulangannya baik pemerintah, masyarakat maupun aparat penegak hukum khusunya polisi sebagai pengayom dan pelindung masyarakat. Langkah-langkah pencegahan dan memutuskan mata rantai penyebab kenakalan remaja tersebut harus dilakukan lebih cepat dan tepat, demi untuk keselamatan generasi muda sebagai asset bangsa yang kelak akan melanjutkan tongkat estafet kepemimpinan bangsa dan negara ini menuju hari esok dan masa depan yang lebih baik. Polisi sebagai aparat negara berperan besar dalam menyusun strategi penanggulangan sekaligus langkah nyata dalam menangani masalah tersebut di lapangan. Hal ini sesuai yang tertera dalam UU RI No. 2 tahun 2002 tentang fungsi kepolisian bahwa: "Fungsi pemerintah negara dibidang pemeliharaan keamanan dan ketertiban masyarakat, penegakan hukum, poerlindungan, pengayoman dan pelayanan kepada masyarakat". Kepolisian Sektor (Polsek) di Kecamatan punya andil besar dalam penanganan kenakalan remaja di setiap wilayah kecamatan, dengan wewenang secara penuh dalam menangani segala bentuk pelanggaran melawan hukum di wilayah 
kerjanya. Fenomena kenakalan remja di era modern dewasa ini kerap terjadi. Hal ini menjadi tantangan tersendiri bagi aparat kepolisian sektor kecamatan, khususnya di polisi Sektor Kajuara, yang berada di tengah dinamika budaya hidup yang cukup keras dalam situasi lingkungan modern yang masih kental primordialnya.

\section{LANDASAN TEORI}

Menurut Muhibbin Syah (1995: 50) memperjelas tentang sub-sub masa remaja adalah Masa remaja (adolescence) terdiri atas sub-sub masa perkembangan yang terdiri atas 3 bagian yaitu 1) sub perkembangan prapuber selama kurang lebih dua tahun sebelum masa puber, 2) sub perkembangan puber selama dua setengah sampai tiga tahun, 3) sub perkembangan post puber, yaitu perkembangan biologis sudah lambat tapi masih terus berlangsung pada bagian-bagian organ-organ tertentu. Masa-masa perkembangan tersebut pada remaja mengalami juga berbagai macam tahapan krisis. Di mana krisis identitas versus difusi identitas, krisis ini harus di atasi. Perubahan biologis dan sosial memungkinkan terjadinya dua bentuk integrasi terjadi pada kepribadian remaja yaitu terbentuknya perasaan akan konsistensi dalam kehidupannya dan tercapainya identitas peran, kurang lebih dengan cara menggabungkan motivasi, nilai-nilai, kemampuan dan gaya yang dimiliki remaja dengan peran yang dituntut dari remaja.

Pada saat ini merupakan akhir masa puber yang mulai menampakkan tanda-tanda kedewasaan.Pada masa remaja, biasanya remaja terjerumus dalam kenakalan remaja.Perbuatan dikatakan kenakalan apabila perbuatan-perbuatan tersebut bertentangan dengan norma-norma yang ada pada masyarakat di mana ia hidup dan berada menetap. Perbuatan-perbuatan tersebut juga tergolong anti sosial dan terkadang mengandung unsur-unsur anti normatif dan terkadang juga dikategorikan penyakit sosial atau penyakit masyarakat.

Gejala penyimpangan secara sosial kenakalan remaja dapat dikelompokkan dalam satu defektif secara social dan mempunyai sebab musabab yang majemuk.Jadi sifatnya multi kausal. Menurut Kartini Kartono (1998: 25:34), mengemukakan tentang teori mengenai sebab terjadinya kenakalan remaja sebagai berikut teori biologis, teori psikogenis, teori sosiogenis, teori Subkultural.

Melihat fenomena kenakalan remaja cukup marak terjadi di kota-kota besar yang cukup memberi virus kepada remaja di desa cukup mencengankan karena fenomena itu juga sudah terjadi di desa.Membuat kekhawatiran kita semua karena pelaku kenakalan remaja itu kebanyakan masih berstatus pelajar aktif. Fakta-fakta ini cukup membingunkan 
karena seharusnya pelajar sebagai generasi terpelajar tidak melakukan kegiatan melawan hukum berupa penganiayaan yang membahayakan dirinya dan orang lain, sementara kenakalan remaja juga melibatkan para remaja yang bestatus pelajar. Kembali Kartini Kartono (1998: 109-110), memberi penguatan terhadap fenomena ini dengan mengungkapkan faktor penyebab terjadinya kenakalan remaja dikalangan remaja berupa penganiayaan akibat dari perkelahian masal pelajar bahkan antar sekolah adalah kegemaran berkelahi antar anak sekolah disebabkan oleh dua faktor, yaitu faktor internal dan faktor eksternal. Dimana faktor internal berlangsung lewat internalisasi diri yang keliru oleh anak-anak remaja terhadap ketidak mampuan mereka melakukan adaptasi terhadap lingkungan sekitar. Sedangkan faktor eksternal atau faktor sosial adalah semua peransang dan pengaruh luar yang menimbulkan tingkah laku tertentu pada anak-anak remaja berupa tindak kekerasan, kejahatan, perkelahian dan seterusnya.

Dalam masyarakat beradab, negara adalah satu-satunya lembaga yang memiliki kewenangan melakukan kekerasan (represi) terhdap pihak-pihak siapa saja yang membuat keonaran, mengganggu keamanan, pelaku kejahatan dan atau pelanggar hukum dan ketertiban lainnya. Mewakili negara yang dimaksud adalah lembaga Kepolisian Republik Indonesia.Memang disadari bahwa masih banyak hal yenag perlu diperbaiki, tetapi komitmen dan gerakan untuk perubahan sudah kelihatan nyata di tengah-tengah masyarakat.Tantangan Polisi sebagai penjaga ketertiban masyarakat semakin besar seiring dengan perkembangan zaman. Satu hal yang cukup potensial mengganggu Kemanan dan Ketertiban Masyarakat (Kamtibmas) adalah masalah kenakalan remaja, penyalahgunaan narkotika zat adiktif lainnya yang kesemuanya itu mengandung unsurunsur kejahatan.Ada beberapa dasar kebijakan Polri dalam rangka menanggulangi kejahatan yaitu:

1. Mencegah kejahatan adalah lebih baik dari pada mencoba mendidik para penjahat menjadi baik kembali.Prinsip Polisi tersebut yang mnegedepankan pencegahan merupakan langkah konstruktif yang cukup positif. Dan hal ini harus terjadi dan dilakukan pada para remaja yang belum masuk dalam area pergaulan salah yang bakal menyimpang kemudian menjadi kenakalan remaja. Kalau itu menjadi gerakan bersama maka yakin remaja akan bisa diselamatkan secara cepat ketimbang mengobatinya akan membutuhkan waktu lama.

2. Penyidikan kejahatan hanya ditujukan demi perlindungan Hak-hak asasi manusia.Penyidikan dan pengusutan pada tingkat pertama biasanya untuk mencari kebenaran materil tentang sesuatu yang terjadi apakah salah atau benar, ada bukti dan 
ada pelaku. Jika semnuanya jelas maka jatuh vonis pada pelaku. Tentunya Polisi dalam mengambil keputusan akhir tentu berdasarkan pada norma-norma yang berlaku diu masyarakat sehingga keputusan akhir tetap menjunjung perlindungan hak asasi manusia.

\section{METODE PENELITIAN}

Jenis penelitian yang dilakukan adalah penelitian deskriptif kualitatif yang bersifat deskriptif dalam bentuk analisis yuridis sosiologisyang bertujuan untuk memahami peranan kepolisian Kajuara dalam penanggulangan kenakalan remaja di Kabupaten Bone.Informan ditentukan secara purposive sampling, dan juga menggunakan sumber data primer dan data sekunder, teknik pengumpulan data yaitu observasi, wawancara dan dokumentasi, kemudian dianalisis melalui tahapan pengumpulan data (data collection), reduksi data (data reduction), penyajian data (display data), penarikan kesimpulan (verification).

\section{PEMBAHASAN}

\section{Faktor Penyebab Terjadinya Kenakalan Remaja}

Hasil penelitian diatas maka penelitian dapat mengetahui bahwa ada beberapa faktor yang menjadi penyebab terjadinya penomena kenakalan remaja di Kecamatan Kajuara Kabupaten Boneadalah pertama, kurangnya perhatian orangtua pada anaknya. Kedua, kurang teladan dari orang tua. Ketiga, Kurang pendidikan agama dalam keluarga. berikut:

a. Secara Biologis

Teori ini menekankan pada faktor fisiologis, struktur jasmaniah seseorang, dan bahkan cacat jasmaniah yang di bawa sejak lahir.Peneliti tidak mendalami keterkaitan secara mendalam terjadinya kenakalan dengan unsur teori ini karena secara fisik pelaku tidak bisa dilihat karena sudah terjadi kasusnya dan tidak ada lagi dalam sel tahanan Polisi ketika peneliti di lokasi penelitian.Sejalan dengan hal tersebut, salah satu anggota Polisi Sektor Kajuara Aiptu Amiruddin (Kanit Sabhara) mengatakan bahwa dari sekian dari kasus yang ditangani yang melibatkan remaja, di kantor Polsek Kajuara belum menemukan secara signifikan adanya pemgaruh unsur fisik pada remaja berpengaruh besar melakukan tindakan kriminal, semuanya masih heterogen penyebabnya.

b. Secara Psikogenis

Psikogenis disebabkan oleh tingkah laku delinkuen anak-anak dari aspek 
psikologis atau isi kejiwaannya, seperti sikap-sikap salah, fantasi dan internalisasi diri yang keliru dan kelalaian orang tua. Perilaku ini kebanyakan dilakukan oleh anak-anak remaja ketimbang orang dengan kedewasaan muda.Remaja dengan kondisi psikogenis biasanya tidak mengindahkan norma-norma moral yang berlaku di masyarakat.

c. Secara Sosiogenis

Teori ini menekankan murni pada unsur sosiologisnya seperti pengaruh struktur sosial yang deviatif, tekanan kelompok, peranan sosial, dan status sosial.Selain itu yang dominan terkait kenakalan remaja ini adalah faktor kultural dan sosial, bahkan hal tersebut mampu mengalahkan struktur lembaga-lembaga sosial dan peranan sosial setiap individu di tengah-tengah masyarakat.Selanjutnya keluarga secara potensial dapat membentuk pribadi anak menjadi hidup secara bertanggung jawab, apabila usaha pendidikan dalam keluarga itu gagal, akan terbentuk seorang anak yang lebih cenderung melakukan tindakan-tindakan yang bersifat kriminal.

\section{d. Secara Subkultur}

Subkultur delinkuen gang remaja itu mengaitkan sistem nilai, kepercayaan/ keyakinan, ambisi-ambisi tertentu seperti ambisi materil, hidup bersantai, pola kriminal, relasi heteroseksual bebas, dan lain-lain yang memotivasi timbulnya kelompok-kelompok remaja berandalan dan kriminal. Perangsang terjdinya hal tersebut karena hadiah mendapatkan status sosial "terhormat" di tengah-tengah kelompoknya, prestise sosial, relasi sosial yang intim, dan hadiah-hadiah yang berbau materialis lainnya.

\section{Upaya Polsek Kecamatan Kajuara dalam Menanggulangi Kenakalan Remaja}

Polisi Sektor Kajuara dalam menangani masalah kenakalan remaja melakukan kiat-kiat sebagai berikut:Pertama, bekerjasama dengan Diknas. Polisi Sektor Kajuara bersama-sama dengan Dinas Pendidikan Nasional mengadakan pembinaan serta penyuluhan tentang masalah-masalah yang terjadi, seperti penyuluhan mengenai narkoba serta seks bebas kepada anak-anak sekolah mulai tingkat SMP sampai SMA yang diadakan setiap tahun ajaran baru.Kedua $a_{s}$ Kerjasama dengan Dinas Kesehatan. Polisi Sektor Kajuara dengan bantuan Dinas Kesehatan melakukan pemeriksaan urine terhadap siswa-siswa yang dicurigai terlibat dengan narkoba.

Dapat ditarik benang merahnya bahwa Polsek Kajuara mampu dandapat melaksanakan tugas dan fungsi kepolisian dalam menciptakan dan meningkatkan keamanan dan ketertiban masyarakat,serta memiliki integritas yang tinggi dalam menyelesaikan persoalan-persoalan kemasyarakatan dengan melibatkan segala lapisan masyarakat. Dengan demikian, dapat dikatakan bahwa motto Polri "Polri Mitra 
Masyarakat" dapat diwujudkan diwilayah hukum Polsek Kajuara.

\section{KESIMPULAN}

Setelah melakukan penelitian, maka peneliti dapat menyimpulkan beberapa kesimpulan untuk menjawab masalah yang di angkat dalam penelitian ini, kesimpulan yang dapat ditarik yaitu :

1. Polsek Kajuara sangatberperandalammenciptakandan meningkatkan keamanan dan ketertiban masyarakat khususnya dalam menanggulangi kenakalan remaja diwilayah hukumnya, yaitu Kecamatan Kajuara, dimana dalam 4 (empat) tahun terakhir (200112015) trend perkembangan kenakalan remaja telah menunjukkan adanya kecenderungan penekanan, yaitu berkisar 2 sampai 3 kasus dalam setahun. Keberhasilan Polsek Kajuara dapat menekan angka kenakalan remaja pada angka maksimal 3 (tiga) kasus/ tahun tidak terlepas adanya disiplin yang tinggi dari seluruh anggotaPolsek Kajuara dan koordinasi, komunikasi serta perdebatan yang baik dengan seluruh komponen masyarakat dan aparat pemerintah Kecamatan dan Desa. Berdasarkan hasil wawancara, menunjukkan bahwa masyarakat menyatakan Polsek Kajuara dapat melaksanakan tugas pokok dan fungsi dengan baik, memiliki kepedulian yang tinggi, mampu menyelesaikan berbagai persoalan kenakalan remaja yang terjadidan keberadaan Polsek dapat dirasakan oleh masyarakat sebagai pengayom dan pelindung masyarakat.

2. Upaya yang dilakukan Polsek Kajuara untuk lebih meningkatkan penanggulangan kenakalan remaja agar situasi selalu terjaga dan terpelihara dengan baik adalah dengan berusaha meningkatkan kemampuan dan keterampilan anggota Polsek, diantarannya adalah :

a. Kemampuan membangun hubungan kemitraan, koordinasi kerja dan komunikasi yang baik dengant tokoh-tokoh masyarakat, perangkat Desa dan perangkat Kecamatan, serta dengan Muspika,

b. Kemampuan anggota Polsek baik fisik maupun mental, terutama dalam menghadapi bermacam objek sentuhan kerja yang membutuhkan penanganan khusus,

c. Kemampuan dalam memantau situasi dan kondisi kerja agar selalu terbaca,

d. Kemampuan managerial dan kemampuan mengambil keputusan secara cepat tepat, dan akurat,

e. Kemampuan untuk melakukan upaya pembinaan maupun penyelenggaraan operasi- 
operasi kepolisian guna menciptakan kondisi yang kondusif.

\section{DAFTAR PUSTAKA}

Ali, M. (1985). Penelitian Pendidikan-Prosedur dan Strategi. Bandung: Aksara

Arikunto, Suharsimi. (1999). Prosedur Penelitian (Suatu Pendekatan Praktek). (Edisi Revisi) Jakarta: Rineka Cipta

Basrowi. (2005). Pengantar Sosiologi, Ghalia Indonesia. Bogor.

Kartono, Kartini. (2006). Patologi Sosial 2 Kenakalan Remaja. Jakarta: PT. Raja Grafindo Persada.

Kartono, Kartini. (1988). Psikologi Sosial. Rajawali Pers. Jakarta.

Kelana, Momo. (1994). Hukum Kepolisian. Jakarta: Grasindo

Mas'udi, Masdar Farid. (2010). Syarah UUD 1945 Perspektif Islam (edisi baru). Tangerang Selatan: PT. Pustaka Alfabet.

Miles Matthew B dan A, Michael Huberman.(1992). Analisis Data Kualitatif.Jakarta: Remaja Rosdakarya.

Moleong, J. Lexy. (2002). Metodologi Penelitian Kualitatif. (Edisi Revisi) Bandung: Remaja Rosdakarya.

Musbikin, Imam. (2013). Mengatasi Kenakalan Siswa Remaja. Pekanbaru Riau: Zanafa Publishing.

Poerwandari, E. K. (1980). Pendekatan Kualitatif Dalam Penelitian Psikologi. Jakarta. Lembaga Pengamatan Sarana Pengukuran Dan Pendidikan Psikologi (LPSP3) Fakultas Psikologi Universitas Indonesia.

Prakoso, Djoko. (1987). Polri Sebagai Penyelidik dan Penegakan Hukum. Jakarta: PT. Bina Aksara.

Prasetyo, Bambang dan Lina Miftahul Jannah. (2005). Metode Penelitian Kuantitatif (teori dan praktek). Jakarta: Raja Grafindo.

Ristzer, George. (2012). Teori Sosiologi (Edisi Kedelapan 2012). Yogyakarta: PT. Pustaka Pelajar

Sarwono, W. Sarlitio. (2012). Psikologi Remaja (Edisi Revisi). Jakarta: Rajawali Pers.

Sugiyono. (2004). Statistika Untuk Penelitian. Bandung: Alfabeth

Soedjono. (1982). Menanggulangi Kejahatan. Bandung: IKA

Syah, Muhibbin. (1995). Psikologi Pendidikan (Suatu Pendekatan Baru). Bandung: Remaja Rosdakarya.

Tim Penyusun FKIP Unismuh Makassar. (2012). Pedoman Penulisan Skripsi. Makassar: Panrita Press Unismuh Makassar. 
UU RI No. 22.Tahun. (2002). Kepolisian Negara Republik Indonesia. Bandung: Citra Umbara. 